\title{
European Treatment Guidelines for schizophrenia
}

\author{
Wolfgang Gaebel \\ From $1^{\text {st }}$ International Congress on Neurobiology and Clinical Psychopharmacology and European \\ Psychiatric Association Conference on Treatment Guidance \\ Thessaloniki, Greece. 19-22 November 2009
}

One of the concrete projects resolved by the EPA European Platform of Psychiatrists concerns the development and implementation of evidence-based treatment recommendations in psychiatry with an European dimension named 'Recommended Guidance'. The major objective is to improve quality of mental health care in Europe by providing evidence-based information and advice and to identify and minimize health care gaps. To provide such guidance for schizophrenia, one of the most serious and disabling disease in psychiatry and in general, an overview will be given of existing treatment guidelines in Europe. This overview will focus on the one hand on methodological quality, since an international survey in 2005 stated [1], that the methodological quality of the most guidelines was at best moderate. Major objective however will be discussing treatment recommendations regarding core clinical questions like early recognition and intervention, acute and long-term treatment. Participants hopefully from all over Europe are encouraged to engage in the discussion and to provide information from their national/regional treatment guidelines, mostly not available in English (or German) language.

Published: 22 April 2010

\section{Reference}

1. Gaebel, et al: Schizophrenia practice guidelines: international survey and comparison. BJP 2005, 248-55.

doi:10.1186/1744-859X-9-S1-S42

Cite this article as: Gaebel: European Treatment Guidelines for schizophrenia. Annals of General Psychiatry 2010 9(Suppl 1):S42.

Submit your next manuscript to BioMed Central and take full advantage of:

- Convenient online submission

- Thorough peer review

- No space constraints or color figure charges

- Immediate publication on acceptance

- Inclusion in PubMed, CAS, Scopus and Google Scholar

- Research which is freely available for redistribution

Submit your manuscript at www.biomedcentral.com/submit
( Biomed Central 